\title{
Shelf Life and Quality Evaluation of Deep Frozen Coconut Cream, Coconut Scrapings and Coconut Slices
}

\author{
L.A.C.N. Lihinikadu Arachchi, K.D.P.P. Gunathilake*, V.P.N. Prasadi
}

\begin{abstract}
Coconut kernel is the major energy source in the diets of coconut producing countries. Ready to use coconut milk/kernel has a great demand in the market specifically for its nutty flavor. Studies were conducted to evaluate the storage quality of deep frozen coconut cream, scraped coconut and coconut slices. Coconut cream pasteurized and scraped coconut and coconut slices were blanched at $70{ }^{\circ} \mathrm{C}$ for 1.5 minutes. A known weight of each product was packed in nylon low density polyethylene, triple laminate and polyethylene and stored in a freezer at $-18{ }^{\circ} \mathrm{C}$. The shelf life was evaluated by free fatty acid content (FFA), peroxide value (PV) and total microbial load. The acceptability was tested using a triangle test with a 25 semi trained panelists in two weeks intervals for two months. FFA content increased during the storage period, but none of the products exceed the standard level of $1 \%$ The development of FFA in products packed in triple laminates was slow and peroxides were not detected up to 8 weeks of storage period. At the $8^{\text {th }}$ week, microbial count reached to $10^{6}$. Sensory study revealed that the organoleptic properties of all three coconut products were within the acceptable range though products showed differences sometimes, after 4 weeks storage compared with fresh samples. The results indicated that the minimum shelf life of the frozen coconut products is 8 weeks.
\end{abstract}

Keywords: coconut milk, coconut kernel, coconut cream, shelf life

\section{Introduction}

Coconut (Cocos nucifera) is unique, providing a host of products and by products with distinctive applications at home and in industry (Taufikkurahman, 1998). Coconut milk/cream is one of the major products produced from coconut kernel, also known as coconut meat, which plays a vital role in the diets of coconut producing countries mainly for its specific nutty flavor and for its nutritional value. Coconut scrapes and slices also intermediate product and coconut milk easily can extract from them.

Coconut milk forms an integral ingredient cuisine of the people of the coconut producing countries. However, the storage life of these coconut products is limited due to the development of rancid odour and flavor mainly by the enzymes present, especially catalase and peroxidase, and by the action of micro organisms (Ranganna, 2000). ). In order to overcome this problem a technique of frozen coconut products such as coconut cream, scrapped/sliced coconut was developed which make easy to obtain coconut milk for the local consumers and for the international market as well.

Department of Food Science \& Technology, Faculty of Livestock, Fisheries \& Nutrition, Wayamba University of Sri Lanka, Makandura, Gonawila, Sri Lanka.

*Corresponding author: kdppgunathilake@yahoo.com 
Commercially, shelf life extension of liquid coconut products has been achieved primarily through canning, aseptic packaging and spray drying (Seow \& Gwee, 1997). With respect to the different methods employed to extend the shelf life of coconut products, a very little work has been carried out on investigating how freezing could be applied to the coconutkernel products for the extension of shelf life of them. Further, in contrast to spray drying techniques, the cost of production of frozen coconut products is low and reliable as it use in its fresh form. Therefore this study was carried out to evaluate the freezing of a few coconut based products such as coconut slices, scrapped coconut and coconut cream for commercial application and product diversification.

\section{Materials and methods}

\subsection{Materials}

Coconuts (variety: CRIC 60) were obtained from the Bandirippuwa estate of Coconut Research Institute. All the chemicals used in the study were of analytical grade, unless otherwise specified. All the instruments used in this study made available at the Coconut Research Institute, Lunuwila, Sri Lanka.

\subsection{Sample preparation}

Scraped coconut meat without brown testa was fed in to a Hydraulic Press machine (Sakaya, Thailand) and the coconut cream was obtained without addition of water for coconut cream extraction. Coconut scrapings without brown testa and coconut kernel without brown testa grated to produce scraped coconut and coconut slices $(0.2 \mathrm{~mm}$ thickness $)$ respectively based on domestic techniques practicing around the region.

\subsection{Pretreatments}

Each product subjected to steam at $70^{\circ} \mathrm{C}$ temperature for 1.5 minutes to inactivate the enzymes present. Then each product was packed $(100 \mathrm{~g})$ in three different packaging materials (Nylon LDPE $(30 \mu \mathrm{m})$, Triple Laminate and Polyethylene $(30 \mu \mathrm{m})$ and kept under frozen storage in a home freezer at $-18^{\circ} \mathrm{C}$.

\subsection{Storage studies of deep frozen coconut based products}

\section{Free fatty acid value}

The frozen coconut cream, scraped coconut and coconut slices were analyzed for the Free Fatty Acid (FFA) content and Peroxide Value (PV) in two weeks intervals for two months. The FFA content was determined using the AOAC method 922.02 (2002). The percentage FFA was calculated as lauric acid (molecular weight $=200.32$ ), considering lauric acid to be the predominant fatty acid present in the coconut kernel.

\section{Peroxide value}

The PV was determined as recommended by the method of the Association of Official Analytical Chemists (AOAC, 1998) for which it was necessary to extract the oil content from the coconut products. Hence, a modification of the method for extraction of oil from food material suggested by Egan, Kirk, and Sawyer (1981) was carried out.

\section{Microbiological analysis}

Total Plate Count (TPC) was determined for each product separately in each packaging material at two weeks intervals using pour plate method. Standard pour plate method used in this study was according to Microbial test methods (SLS- 516, Part- 1, 1991). Plate count agar used as the culture medium and the resultant colonies were counted after 48 hours of incubation.

\section{Sensory evaluation}

Frozen coconut cream, scraped coconut and coconut slices evaluated by subjecting to general scrutiny such as observations on odour, taste, appearance, colour and overall acceptability in two weeks intervals using 25 semi trained panelists. The products packed triple laminates only used in the evaluation of sensory property changes under Triangle Test and interpret the results under 0.05 significance level.

\section{Statistical analysis}

All the data collected from the study were presented as mean \pm standard deviation of three 
replications. Samples were analyzed in triplicate and one way analysis of variance (ANOVA) was performed, using general linear model (SAS 9.2, Cary, NC). Differences were considered to be statistically significant if the probability values were less than $0.05(\mathrm{p}<0.05)$. When there were significant differences, multiple mean comparisons were carried out using LSD method.

\section{Results and discussion}

\subsection{Free fatty acid value and peroxide value}

Figure 1, 2 and 3 show the changes in free fatty acids levels of three coconut based products during frozen storage. Coconut cream packed in polyethylene showed significantly higher rate of FFA changes compared with coconut cream packed with other two packaging materials. Among the packing material tested, the slowest changes in FFA\% during frozen storage were observed in coconut cream packed in Triple laminate package.

Stored coconut slices also exhibits lowest FFA levels in triple laminated package. Highest FFA values and highest rate of increase were observed in slices stored in polythene packages. Lowest values for FFA content were observed in nylon LDPE while FFA levels were highest rate of increase was observed in coconut scrapes packed in polyethylene packs.

Figure 1 shows the FFA content is gradually increased with the storage period. At the starting point scraped coconut and coconut slices have slightly similar FFA content which is also higher for the coconut cream. As the coconut slices and scraped coconut having comparatively a higher amount of fat/unit the FFA contents also higher in them. The critical limit for FFA is 1\% (Gunathilake, 2006). During the storage period any of the products did not exceed this limit.

Free fatty acid content The FFA content of fresh coconut kernel was $0.02 \pm 0.1 \%$ as lauric acid. Similar values were reported by Gunathilake and Jayasekera (2003). However, Cancel (1979) and Waisundera et al., (2007) reported that the FFA content of fresh coconut kernel was $0.55 \%$ as lauric acid. The FFA content of the control samples, increased steadily with increase in storage time. However, the level of increment is low in all three products. This may be due to the microbial lipase that may have been produced due to some growth of microorganisms during frozen storage although coconut samples were blanched or pasteurized at $70{ }^{\circ} \mathrm{C}$. However, the increment within two months study was below $0.06 \%$ as lauric acid in all coconut products stored in any packaging materials tested. This could be associated with the some arrestment of lipase by freezing conditions.

The peroxide value indicates the rancidity value of 35.5 meq of peroxide $\mathrm{O}_{2}$ per $\mathrm{kg}$ of oil (Anon, 1985). All coconut samples had the peroxide values below 35.5 meq of peroxide $\mathrm{O}_{2}$ per $\mathrm{kg}$ of oil, indicating that the coconut samples were not classified as rancid within the two months storage period. The value of peroxide values of all samples were remains constant throughout the storage period. In fact there was no apparent rancid odor in any of the frozen samples. This shows that the mild heat treatment at $70{ }^{\circ} \mathrm{C}$ given to the coconut products were adequate to inactivate peroxidase lipoxygenase enzymes. Similar results were observed in the research by McLellan and Robinson (1981) on peroxidase and lipoxygenase enzymes of Brussel Sprouts and cabbage, where the PV decreased along with the peroxidase and lipoxygenase enzyme activities.

\subsection{Sensory Evaluation}

Table 1shows the probability values of the sensory attributes of deep frozen coconut products.

Only the products packed in triple laminates were used in the sensory evaluation. Frozen products were compared with fresh coconut products for the comparison. The flavor and colour of coconut cream was insignificant during 8 weeks storage period when compared with fresh coconut cream samples. However, it was observed the separation of fat layer in coconut cream due to unstable nature of wateroil emulsion in coconut cream. 


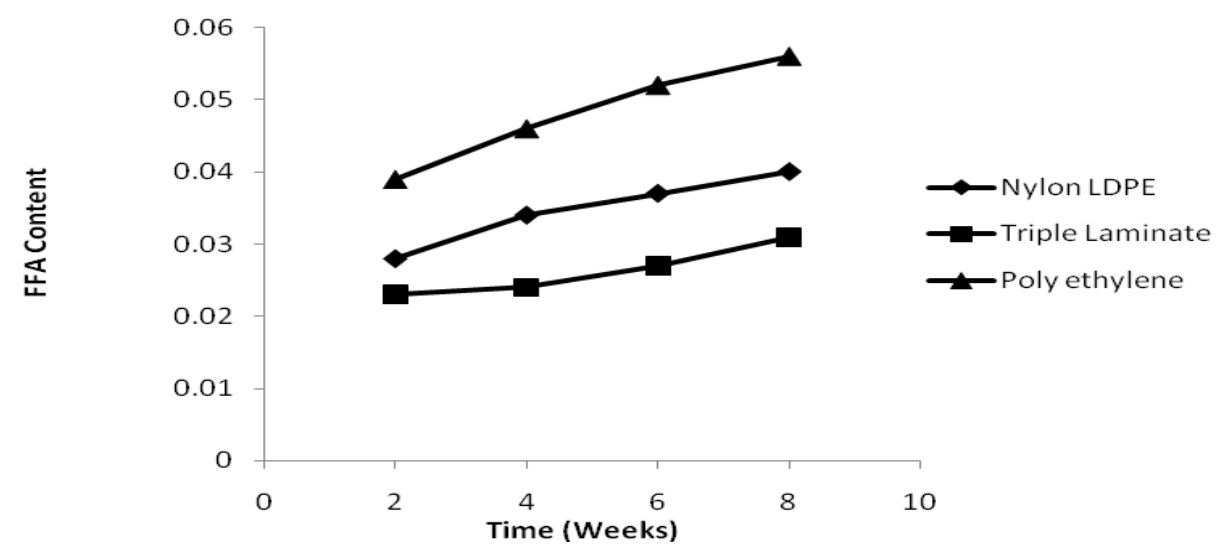

Figure 1. Variation of FFA content of coconut cream in frozen storage

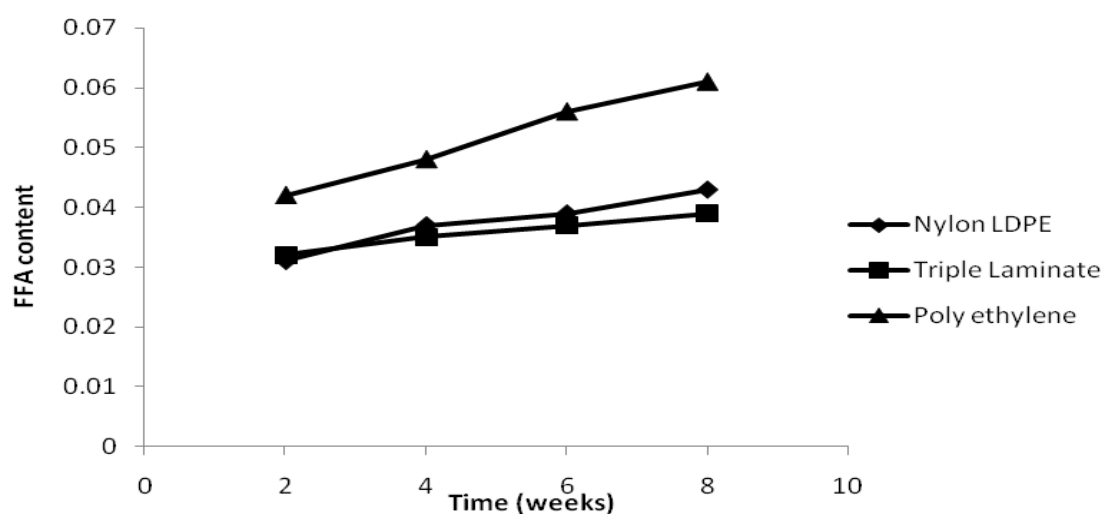

Figure 2. Variation of FFA content of coconut slices in frozen storage

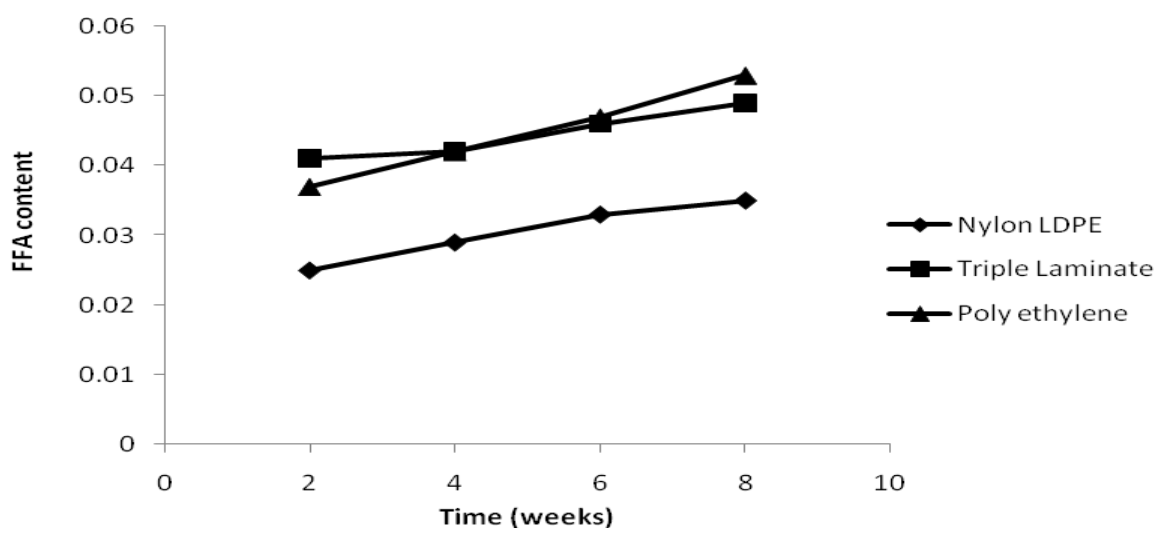

Figure 3. Variation of FFA content of coconut scrapes in frozen storage 
Table 1. The probability values of the sensory attributes of deep frozen coconut products

\begin{tabular}{cccc}
\hline Storage time (weeks) & \multicolumn{3}{c}{ P value } \\
\cline { 2 - 4 } & Coconut cream & Coconut slices & Coconut scraped \\
\hline 2 & 0.063 & 0.013 & 0.01 \\
\hline 4 & 0.092 & 0.013 & 0.01 \\
\hline 6 & 0.092 & 0.013 & 0.848 \\
\hline 8 & 0.194 & 0.038 & 0.92
\end{tabular}

Probability value $(\mathrm{P}<0.05)$ significant level

Table 2. Variation of TPC (cfu/g) of frozen coconut products depending on the packaging material

\begin{tabular}{|c|c|c|c|c|}
\hline & \multirow{2}{*}{$\begin{array}{c}\text { Storage } \\
\text { duration } \\
\text { (weeks) }\end{array}$} & \multicolumn{3}{|c|}{ Packaging material } \\
\hline & & Nylon LDPE & $\begin{array}{c}\text { Triple } \\
\text { Laminate }\end{array}$ & Poly ethylene \\
\hline \multirow[t]{5}{*}{ Coconut cream } & $\mathbf{0}$ & $2.14 * 10^{3}$ & $2.14 * 10^{3}$ & $2.14 * 10^{3}$ \\
\hline & 2 & $2.65 * 10^{4}$ & $2.44 * 10^{4}$ & $2.48 * 10^{4}$ \\
\hline & 4 & $2.80 * 10^{4}$ & $2.68 * 10^{4}$ & $2.75^{*} 10^{4}$ \\
\hline & 6 & $1.54 * 10^{5}$ & $2.30 * 10^{5}$ & $2.30 * 10^{5}$ \\
\hline & 8 & $2.01 * 10^{6}$ & $1.67 * 10^{6}$ & $2.02 * 10^{6}$ \\
\hline \multirow[t]{5}{*}{ Coconut slices } & $\mathbf{0}$ & $2.05 * 10^{3}$ & $2.05 * 10^{3}$ & $2.05 * 10^{3}$ \\
\hline & 2 & $2.37 * 10^{4}$ & $2.25 * 10^{4}$ & $2.33 * 10^{4}$ \\
\hline & 4 & $2.55^{*} 10^{4}$ & $2.53 * 10^{4}$ & $2.65 * 10^{4}$ \\
\hline & 6 & $1.37 * 10^{5}$ & $1.35 * 10^{5}$ & $1.10^{*} 10^{5}$ \\
\hline & 8 & $1.10^{*} 10^{6}$ & $1.05 * 10^{5}$ & $1.33 * 10^{6}$ \\
\hline \multirow[t]{5}{*}{ Scraped coconut } & $\mathbf{0}$ & $1.97 * 10^{3}$ & $1.97 * 10^{3}$ & $1.97 * 10^{3}$ \\
\hline & 2 & $2.55^{*} 10^{4}$ & $2.34 * 10^{4}$ & $2.37 * 10^{4}$ \\
\hline & 4 & $2.78 * 10^{4}$ & $2.43 * 10^{4}$ & $2.58 * 10^{4}$ \\
\hline & 6 & $1.55 * 10^{5}$ & $1.91 * 10^{5}$ & $1.33 * 10^{5}$ \\
\hline & 8 & $1.83 * 10^{6}$ & $0.35 * 10^{6}$ & $1.25 * 10^{6}$ \\
\hline
\end{tabular}


The sensory properties of Coconut slices on the other hand were also accepted by the panelists although it was significantly different when compared with fresh coconut slices samples. The organoleptic properties of scraped coconut were significantly different during first 4 weeks of storage although the panelists have indicated that the organoleptic properties of the frozen slices were within the acceptable range in the ranking. However, more interestingly, there were no significant differences were observed between from scraped coconut with fresh samples after 4 weeks of frozen storage.

\subsection{Microbiological analysis}

Table 2 shows the variation of microbial load (cfu/g) of frozen coconut products depending on the packaging materials.

It was observed that the total microbial load increased within the storage period. This can be due to the some level of proliferation of micro organisms in the packed products at the studied freezing conditions. At the $8^{\text {th }}$ week the microbial count were reached to $10^{6}$ in all three products.

\section{Conclusion}

These results suggest that the mild heat treatment $\left(70{ }^{\circ} \mathrm{C}\right)$ for three coconut products were successful in the elimination of peroxidases as no changes in peroxide values were observed. However, the level of heat treatment may not sufficient to completely arrest of microbial lipases as little increment of free fatty acids were observed during 8 weeks storage. However, all three products were organoleptically acceptable after 8 weeks of frozen storage. Therefore, fresh coconut cream, slices and scrapings may be blanched and stored frozen for minimum of eight weeks of time within the "acceptable" limit.

\section{Acknowledgement}

The authors acknowledge the assistance provided by Coconut Processing Research Division of Coconut Research Institute of Sri Lanka.

\section{References}

AOAC (Association of Official Analytical Chemists) (2002) $\quad\left(17^{\text {th }}\right.$ ed.). Official methods of analysis of AOAC International (Vol. 2). Gaithersburg, MD, USA: Association of Official Analytical Chemists.

Anon (1985). "Coconut cream, raw" NDM no. 12115. Nutrition Database, University of Minnesota, USA. (pp. 146-198).

APCC (Asian and Pacific Coconut Community) (1994). International codes and standard for aqueous coconut products (2nd draft) (pp. 35-46). Jakarta: Standards Task Force, Asian and Pacific Coconut Community.

Cancel, L. E. (1979). Coconut food products and bases. In J. G. Woodroof (Ed.), Coconuts: production, processing, products (second ed., pp. 202-239). Connecticut: Westport publications.

Egan, H., R. Kirk, and R. Sawyer. "The Luff Schoorl method. Sugars and preserves." Pearson's chemical analysis of foods 8 (1981): 152-153.

Gunathilake, K. D. P. P., and C. Jayasekera. "Studies on development and storage of bottled penipol." In COCOS, vol. 15, pp. 31-37. 2003.

Gunathilake K.D.P.P., 2006, Application of hurdle techniques to preserve fresh scraped coconut at ambient and refrigerated storage, Journal of National Science Foundation of Sri Lanka, 33(4), 265-268.

McLellan, K. M., \& Robinson, D. S. (1981). Effect of heat on cabbage and Brussels sprout peroxidase enzymes. Food Chemistry, 1, 257-266.

Ranganna, S. Handbook of canning and aseptic packaging. Tata McGraw-Hill Publishing Company, 2000.

Seow, C. C., \& Gwee, C. N. (1997). Coconut milk: chemistry and technology. International Journal of Food Science and Technology, 32,189-201. 
Cord 2016, 32 (1)

Taufikkurahman, L. 1998. Coconut Statistical Yearbook 1977. APCC, Jakarta.

Waisundara, Viduranga Y., Conrad O. Perera, and Philip J. Barlow. "Effect of different pre-treatments of fresh coconut kernels on some of the quality attributes of the coconut milk 